\title{
Spectral Properties and Energy Transfer of a Potential Solar Energy
}

\section{Converter}

\author{
Lei Zhou ${ }^{\mathrm{a}}$, Weijie Zhou ${ }^{\mathrm{a}}$, Fengjuan Pan ${ }^{\mathrm{a}}$, Rui Shi ${ }^{\mathrm{a}}$, Lin Huang ${ }^{\mathrm{a}}$, Hongbin Liang*a \\ Peter A. Tanner* ${ }^{\mathrm{b}}$, Xueyan $\mathrm{Du}^{\mathrm{c}}$, Yan $\mathrm{Huang}^{\mathrm{c}}$, Ye Tao ${ }^{\mathrm{c}}$, Lirong Zheng ${ }^{\mathrm{c}}$ \\ ${ }^{a}$ MOE Laboratory of Bioinorganic and Synthetic Chemistry, State Key Laboratory of Optoelectronic Materials and \\ Technologies, School of Chemistry and Chemical Engineering, Sun Yat-sen University, Guangzhou 510275, P.R. \\ China.
}

E-mail: cesbin@mail.sysu.edu.cn

${ }^{\mathrm{b}}$ The Hong Kong Institute of Education (Education University of Hong Kong, designate), 10 Lo Ping Road, Tai Po, Hong Kong S.A.R., P.R. China

E-mail: peter.a.tanner@gmail.com;

'Beijing Synchrotron Radiation Facility, Institute of High Energy Physics, Chinese Academy of Sciences, Beijing 100039, P.R. China

\section{Supporting Information}

Experimental details

\section{Centroid shift of $\mathrm{Ce}^{3+}$ in CSS}

\section{Energy transfer formulae}

Table S1. The main raw materials and their purity.

Figure $\mathrm{S} 1$. The coordination environments of $\mathrm{Ca}^{2+}$ and $\mathrm{Sc}^{3+}$ sites in $\mathrm{Ca}_{3} \mathrm{Sc}_{2} \mathrm{Si}_{3} \mathrm{O}_{12}$.

Figure S2. The X-ray diffraction refinement of the $\mathrm{Ca}_{3} \mathrm{Sc}_{2} \mathrm{Si}_{3} \mathrm{O}_{12}$ host.

Table S2. Crystallographic Data and Refined Structure Parameters for selected samples. Space group $\operatorname{Ia}-3 d(Z=8)$.

Figure S3. SEM micrographs of CSS precursor (left) and final product (right).

Figure S4. XRD patterns of $\mathrm{Ca}_{3} \mathrm{Sc}_{2} \mathrm{Si}_{3} \mathrm{O}_{12}$ calcined at $1100{ }^{\circ} \mathrm{C}-1400{ }^{\circ} \mathrm{C}$.

Figure S5. Centroid and crystal field splitting in $\mathrm{Ca}_{3} \mathrm{Sc}_{2} \mathrm{Si}_{3} \mathrm{O}_{12}: \mathrm{Ce}^{3+}, \mathrm{Na}^{+}$.

Figure S6. Ce-L3 X-ray absorption near-edge structure in selected samples.

Figure S7. VUV-UV excitation spectra of $\mathrm{Ca}_{2.8} \mathrm{Ce}_{0.1} \mathrm{Na}_{0.1} \mathrm{Sc}_{2} \mathrm{Si}_{3} \mathrm{O}_{12}$ at $15 \mathrm{~K}$. 
Figure S8. The VUV excitation spectra of $\mathrm{Ca}_{3-2 x} \mathrm{Ce}_{x} \mathrm{Na}_{x} \mathrm{Sc}_{2} \mathrm{Si}_{3} \mathrm{O}_{12}(x=0,0.001,0.1$ and 0.2$)$ at 15 K.

Figure S9. The emission spectra of $\mathrm{Ca}_{2.8} \mathrm{Ce}_{0.1} \mathrm{Na}_{0.1} \mathrm{ScSi}_{3} \mathrm{O}_{12}$ under 330, 360 and $440 \mathrm{~nm}$ excitation wavelengths, respectively at RT.

Figure $\mathrm{S} 10$. The emission spectra of $\mathrm{Ca}_{2.8} \mathrm{Ce}_{0.1} \mathrm{Na}_{0.1} \mathrm{ScSi}_{3} \mathrm{O}_{12}$ at $15 \mathrm{~K}$ excited by synchrotron radiation.

Figure $\mathrm{S} 11$. The emission decay curves of $\mathrm{Ca}_{2.8} \mathrm{Ce}_{0.1} \mathrm{Na}_{0.1} \mathrm{ScSi}_{3} \mathrm{O}_{12}$ at $15 \mathrm{~K}$.

Figure S12.The normalized excitation spectra (according to the highest peak intensity) of $\mathrm{Ca}_{2.8} \mathrm{Ce}_{0.1} \mathrm{Na}_{0.1} \mathrm{Sc}_{2} \mathrm{Si}_{3} \mathrm{O}_{12}$ at various temperatures by monitoring $550 \mathrm{~nm}$ emission.

Figure S13. $13 \mathrm{~K}$ emission and excitation spectra of CSS:0.06 Eu.

Figure $\mathrm{S} 14$. The excitation and emission spectra of $\mathrm{Ca}_{2.94} \mathrm{Eu}_{0.06} \mathrm{Sc}_{2} \mathrm{Si}_{3} \mathrm{O}_{1} 2$ at $13 \mathrm{~K}$.

Figure $\mathrm{S} 15$. The excitation spectra of the samples $\mathrm{Ca}_{3-x} \mathrm{Eu}_{x} \mathrm{Sc}_{2} \mathrm{Si}_{3} \mathrm{O}_{12}(x=0-0.09)$ at RT.

Figure $\mathrm{S} 16$. The decay curves of $\mathrm{Ca}_{3-x} \mathrm{Eu}_{x} \mathrm{Sc}_{2} \mathrm{Si}_{3} \mathrm{O}_{12}$ at RT.

Figure S17. (a) The emission spectra for samples of $\mathrm{Ca}_{2.94} \mathrm{Eu}_{0.06} \mathrm{Sc}_{2} \mathrm{Si}_{3} \mathrm{O}_{12}$ at different

temperatures. Repeated experiments (at different resolution). (b) The temperature dependence of emission was fitted according to the equation: $[\mathrm{I}(T) / \mathrm{I}(0)]=1 /[1+\exp (-E / k T)]$, where $\mathrm{I}(T)$ is the integrated emission band area at temperature $T / \mathrm{K}, E$ is an activation energy and $k$ is the Boltzmann constant. $I(0)$ was taken as the value at $25 \mathrm{~K}$.

Figure S18. The excitation spectra of co-doped samples $\mathrm{Ca}_{2.8} \mathrm{Ce}_{0.1} \mathrm{Na}_{0.1} \mathrm{Eu}_{x} \mathrm{ScSi}_{3} \mathrm{O}_{12}$ at $\mathrm{RT}\left(\lambda_{\mathrm{em}}=\right.$ $550 \mathrm{~nm})$.

Figure S19. The emission spectra $\left(\lambda_{\mathrm{em}}=440 \mathrm{~nm}\right)$ of $\mathrm{Ca}_{2.8-x} \mathrm{Ce}_{0.1} \mathrm{Eu}_{x} \mathrm{Na}_{0.1} \mathrm{Sc}_{2} \mathrm{Si}_{3} \mathrm{O}_{12}$ at room temperature.

Figure S20. (a) Inokuti-Hirayama fits of $\mathrm{Ca}_{2.8-x} \mathrm{Ce}_{0.1} \mathrm{Eu}_{x} \mathrm{Na}_{0.1} \mathrm{Sc}_{2} \mathrm{Si}_{3} \mathrm{O}_{12}$ for $s=10$.

Figure S21. The spectral overlap of the $\mathrm{Ce}^{3+}$ emission spectrum and $\mathrm{Eu}^{2+}$ excitation spectrum. 


\section{EXPERIMENTAL DETAILS}

Materials and synthesis. The phosphors were synthesized by a sol-gel combustion method using the chemicals listed in Table S1. Firstly, the metal nitrate solutions were obtained in stoichiometric proportions by dissolving rare earth oxides in nitric acid. Anhydrous ethanol was added to the resulting solution with heating at $65{ }^{\circ} \mathrm{C}$ to evaporate superfluous water until a transparent sol was obtained. The sol was dried at $95{ }^{\circ} \mathrm{C}$ to form a dry gel which was then fired in a muffle furnace at $700{ }^{\circ} \mathrm{C}$ in air for $3 \mathrm{~h}$ to obtain a precursor. After grinding, the precursor was sintered at $1400{ }^{\circ} \mathrm{C}$ for $6 \mathrm{~h}$ in a $\mathrm{CO}$ reducing atmosphere created by burning activated carbon. The product was reground, washed twice by warm dilute nitric acid and water, and finally ovendried.

Instrumental measurements. The final products were examined on a Bruker D8 Advance type powder X-ray diffractometer, using $\mathrm{Cu}$ Ka radiation $(\lambda=1.5404 \AA)$ and operating at $40 \mathrm{kV}$ and $40 \mathrm{~mA}$. High quality XRD data for Rietveld refinement was collected over a $2 \theta$ range from $5^{\circ}$ to $110^{\circ}$. The structural refinement was performed using the TOPAS-Academic program. The UVexcitation and UV-visible emission spectra at room temperature, as well as the luminescence decay curves, were measured by a FLS920-combined Fluorescence Lifetime and Steady State Spectrometer (Edinburgh Instruments) equipped with a $450 \mathrm{~W}$ Xe lamp and a $150 \mathrm{~W}$ nF900 flash lamp. A TM300 excitation monochromator and two TM300 emission monochromators, equipped with a red sensitive PMT and a R5509-72 NIR-PMT in a liquid nitrogen cooled housing (Hamamatsu Photonics K.K.). Several light sources were employed to excite the emission spectra and measure the luminescence decay curves of the samples. The Ce X-ray absorption near-edge structure (XANES) analysis was carried out in the fluorescence mode at room temperature on the beamline 1W2B of the Beijing Synchrotron Radiation Facility (BSRF). The 
vacuum ultraviolet-ultraviolet visible (VUV-UV) excitation and corresponding emission spectra were recorded at the experimental station on beam line 4B8 of BSRF. The excitation spectra were corrected by the standard sodium salicylate $\left(\mathrm{o}-\mathrm{C}_{6} \mathrm{H}_{4} \mathrm{OHCOONa}\right)$.

Centroid shift of $\mathrm{Ce}^{3+}$ in CSS. The centroid shift of $\mathrm{Ce}^{3+}$ in a specific host lattice is defined as the energy difference from the average position of the split $5 \mathrm{~d}$ energy levels to that of the free $\mathrm{Ce}^{3+}$ ion. It can be estimated according to the following semi-empirical formula: ${ }^{\mathrm{S} 1, \mathrm{~S} 2}$

$$
\varepsilon_{c}=1.79 \times 10^{13} \times \sum_{\mathrm{i}=1}^{\mathrm{N}} \frac{\alpha_{\mathrm{sp}}^{\mathrm{i}}}{\left(\mathrm{R}_{\mathrm{i}}-0.6 \Delta \mathrm{R}\right)^{6}}
$$

Where $\varepsilon_{\mathrm{c}}$ is the shift of the centroid energy in $\mathrm{eV}$ relative to the free $\mathrm{Ce}^{3+}$ ion value $6.35 \mathrm{eV}$ $\left(51212 \mathrm{~cm}^{-1}\right.$, which actually refers to a zero phonon line and not a vibronic band); $\mathrm{R}_{\mathrm{i}}$ is the distance $(\mathrm{pm})$ between $\mathrm{Ce}^{3+}$ and anion $\mathrm{i}\left(\mathrm{O}^{2-}\right)$ in the undistorted lattice; $\Delta \mathrm{R}$ is the radius difference between $\mathrm{Ce}^{3+}$ and the substituted cations $\mathrm{Ca}^{2+}$ (for $\mathrm{CSS}: \mathrm{Ce}^{3+} \Delta \mathrm{R}$ is $2.3 \mathrm{pm}$ ); $0.6 \Delta \mathrm{R}$ is a correction for lattice relaxation around $\mathrm{Ce}^{3+}$; and $\alpha_{\mathrm{sp}}^{\mathrm{i}}\left(10^{-30} \mathrm{~m}^{-3}\right)$ is the spectroscopic polarizability of anion $\mathrm{i}\left(\mathrm{O}^{2-}\right)$, which is closely connected with the polarizability of the anion. The summation is over all $\mathrm{N}$ anions that are coordinated to $\mathrm{Ce}^{3+}$. The value of $\alpha_{\mathrm{sp}}^{\mathrm{i}}$ for oxygen, which is related to the inverse square of the weighted average of the electronegativity of the cations in oxides, can be defined as follows:

$$
\alpha_{s p}^{O}=0.33+\frac{4.80}{\chi_{a v}^{2}}
$$

where $\chi_{\mathrm{av}}$ is the average of the electronegativity of the cation, with $\chi_{\mathrm{av}}=1.43$ for CSS. Including this datum into Eq. S2 gives $\alpha_{\mathrm{sp}}=2.68$ (in units of $10^{-30} \mathrm{~m}^{3}$ ). By this method, the centroid shift is estimated to be $1.42 \mathrm{eV}\left(11455 \mathrm{~cm}^{-1}\right)$. The value is between $11209 \mathrm{~cm}^{-1}\left(\mathrm{Ce}^{3+}-\mathrm{Sc}^{3+}\right.$ model $)$ and $12158 \mathrm{~cm}^{-1}\left(\mathrm{Ce}^{3+}-\mathrm{Na}^{+}\right.$model $)$calculated from first principles. ${ }^{\mathrm{S} 3}$ 


\section{Energy transfer formulae}

The probability of transfer from an excited donor $\mathrm{D}^{*}$ to an acceptor A varies as the square of the matrix element $H_{E S}^{\prime}:$ s4

$$
\begin{aligned}
& \left|<\mathrm{D}, \mathrm{A}^{*}\right| H_{E S}^{\prime}\left|\mathrm{D}^{*}, \mathrm{~A}>\right|=C \sum_{k_{1}, k_{2}}\left(\frac{1}{R^{1+k_{1}+k_{2}}}\right)^{2} x K\left|\mu_{\mathrm{D}}^{\left(k_{1}\right)}\right|^{2}\left|\mu_{\mathrm{A}}^{\left(k_{2}\right)}\right|^{2} \\
& \text { where } \quad C=\left(\frac{1}{4 \pi \varepsilon_{0} K}\right)^{2} \\
& \text { and } \quad K=\frac{\left(2 k_{1}+2 k_{2}\right) !}{\left(2 k_{1}+1\right) !\left(2 k_{2}+1\right) !} \\
& \text { and }\left|\mu_{\mathrm{D}}^{\left(k_{1}\right)}\right|^{2}=\sum_{q_{1}}\left|<\mathrm{D} \mu_{q_{1}}^{\left(k_{1}\right)}\left(r_{\mathrm{D}}\right)\right| \mathrm{D}^{*}>\left.\right|^{2}
\end{aligned}
$$

With a similar equation for $\left|\mu_{\mathrm{A}}^{\left(k_{2}\right)}\right|^{2}$. The other symbols have their usual meanings. ${ }^{\mathrm{S} 3}$ Alternatively, the energy transfer rate from $\mathrm{D}^{*}$ to A for electric dipole-electric dipole energy transfer (dd) may be expressed in terms of oscillator strengths $f(E D)$ and the normalized overlap integral between the donor emission and acceptor absorption: ${ }^{\mathrm{S4}}$

$W_{\mathrm{DA}}^{\mathrm{dd}}=\left(\frac{1}{4 \pi \varepsilon_{0}}\right)^{2} \frac{3 \pi \hbar e^{4}}{n^{4} m^{2} \omega^{2}} \frac{1}{R^{6}} f_{\mathrm{D}}(\mathrm{ED}) f_{\mathrm{A}}(\mathrm{ED}) \int g_{\mathrm{D}}(E) g_{\mathrm{A}}(E) d E$ (Eq. S3b)

The dominant transfer mechanism will be dd when both transitions are ED allowed. 
Table S1. The main raw materials and their purity.

\begin{tabular}{|c|c|c|c|c|c|}
\hline Reagent & $\begin{array}{l}\text { Chemical } \\
\text { formula }\end{array}$ & Purity & Formula Weight & Supplier & Location \\
\hline Calcium nitrate & $\mathrm{Ca}\left(\mathrm{NO}_{3}\right)_{2} \cdot 4 \mathrm{H}_{2} \mathrm{O}$ & analytically pure & 236.15 & $\begin{array}{l}\text { Guangdong } \\
\text { Guanghua } \\
\text { Chemical } \\
\text { Factory } \\
\text { Co. Ltd. }\end{array}$ & $\begin{array}{l}\text { Shantou, } \\
\text { Guangdong, } \\
\text { China }\end{array}$ \\
\hline Cerium oxide & $\mathrm{CeO}_{2}$ & $99.99 \%$ & 172.11 & \multirow[t]{2}{*}{$\begin{array}{l}\text { Guangdong } \\
\text { Zhujiang } \\
\text { Rare Earth } \\
\text { Co. Ltd. }\end{array}$} & \multirow[t]{2}{*}{$\begin{array}{l}\text { Guangzhou, } \\
\text { Guangdong, } \\
\text { China }\end{array}$} \\
\hline Europium oxide & $\mathrm{Eu}_{2} \mathrm{O}_{3}$ & $99.99 \%$ & 351.93 & & \\
\hline Scandium oxide & $\mathrm{Sc}_{2} \mathrm{O}_{3}$ & $99.99 \%$ & 137.91 & $\begin{array}{l}\text { Xiya } \\
\text { Reagent }\end{array}$ & $\begin{array}{l}\text { Chengdu, } \\
\text { Sichuan, } \\
\text { China }\end{array}$ \\
\hline Sodium nitrate & $\mathrm{Na}_{2} \mathrm{CO}_{3}$ & analytically pure & 105.99 & \multirow{4}{*}{$\begin{array}{l}\text { Tianjin } \\
\text { Damao } \\
\text { Chemical } \\
\text { Reagent } \\
\text { Factory }\end{array}$} & \multirow{4}{*}{$\begin{array}{l}\text { Tianjin, } \\
\text { China }\end{array}$} \\
\hline $\begin{array}{l}\text { Silicic acid } \\
\text { tetraethyl ester }\end{array}$ & $\mathrm{Si}\left(\mathrm{OC}_{2} \mathrm{H}_{5}\right)_{4}$ & $\mathrm{SiO}_{2} 28 \%$ & 208.33 & & \\
\hline $\begin{array}{l}\text { Anhydrous } \\
\text { ethanol }\end{array}$ & $\mathrm{C}_{2} \mathrm{H}_{6} \mathrm{O}$ & $99.7 \%$ & 46.07 & & \\
\hline Urea & $\mathrm{CO}\left(\mathrm{NH}_{2}\right)_{2}$ & analytically pure & 60.06 & & \\
\hline Nitric acid & $\mathrm{HNO}_{3}$ & $65 \%-68 \%$ & 63.01 & $\begin{array}{l}\text { Guangzhou } \\
\text { Chemical } \\
\text { Factory }\end{array}$ & $\begin{array}{l}\text { Guangzhou, } \\
\text { China }\end{array}$ \\
\hline
\end{tabular}


Figure S1. The coordination environments of $\mathrm{Ca}^{2+}$ and $\mathrm{Sc}^{3+}$ sites in $\mathrm{Ca}_{3} \mathrm{Sc}_{2} \mathrm{Si}_{3} \mathrm{O}_{12}$.

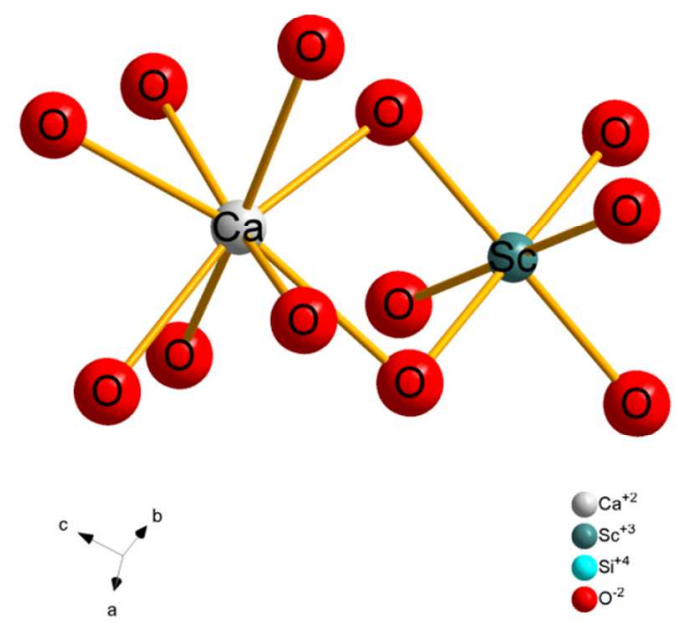

Figure S2. The X-ray diffraction refinement of the $\mathrm{Ca}_{3} \mathrm{Sc}_{2} \mathrm{Si}_{3} \mathrm{O}_{12}$ host.

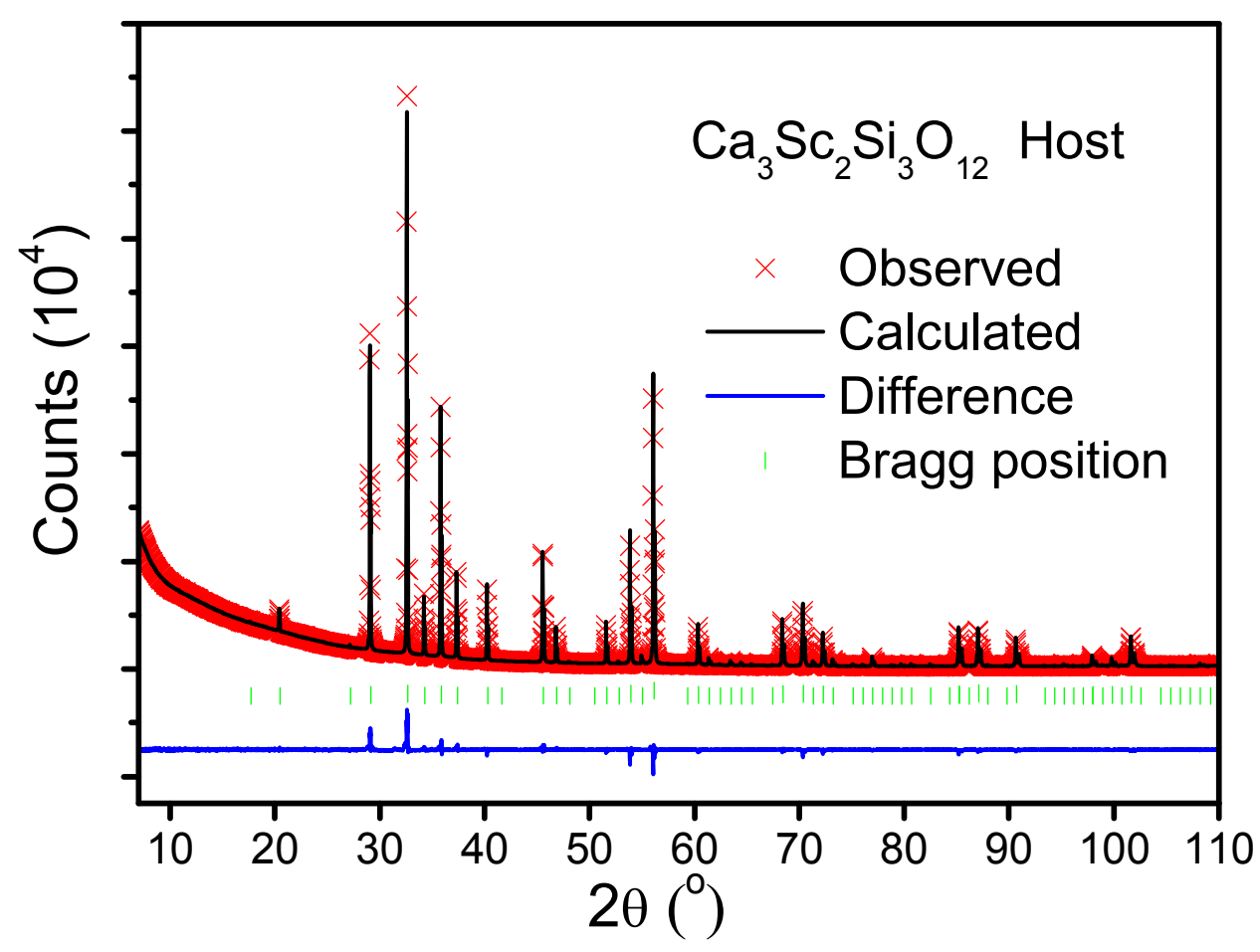


Table S2. Crystallographic Data and Refined Structure Parameters for selected samples. Space group $I a-3 d(Z=8)$.

\begin{tabular}{llll}
\hline \hline \multicolumn{1}{c}{ Sample } & \multicolumn{1}{c}{ CSS } & CSS:0.03Ce & CSS:0.03Eu \\
\hline \hline Cell parameters & & & \\
$\mathrm{a}=\mathrm{b}=\mathrm{c}(\AA)$ & $12.24823(3)$ & $12.24900(3)$ & $12.24930(3)$ \\
$V\left(\AA^{3}\right)$ & $1837.47(1)$ & $1837.81(1)$ & $1837.95(1)$ \\
Reliability factor & & & \\
$R_{\mathrm{wp}}(\%)$ & 3.72 & 3.33 & 2.98 \\
$R_{\mathrm{p}}(\%)$ & 2.05 & 1.90 & 1.70 \\
$R_{\mathrm{B}}(\%)$ & 4.37 & 4.89 & 2.70 \\
\hline \hline
\end{tabular}

Figure S3. SEM micrographs of CSS precursor (left) and final product (right).

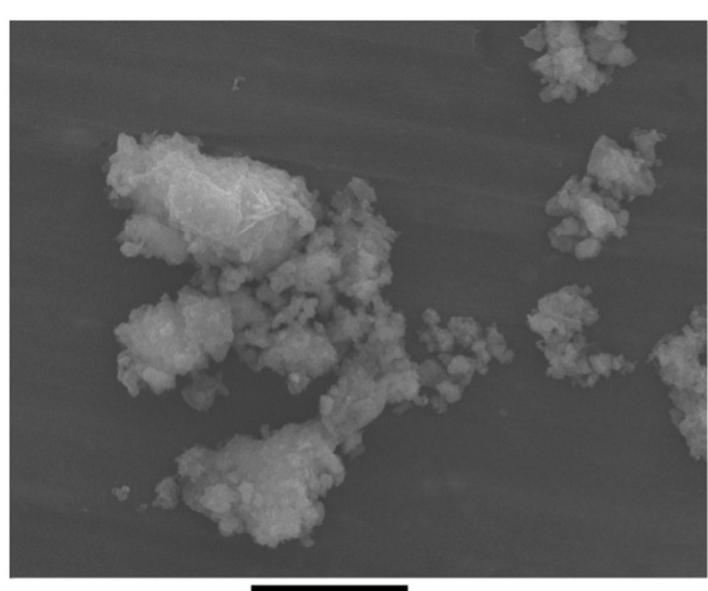

$5.0 \mu \mathrm{m}$

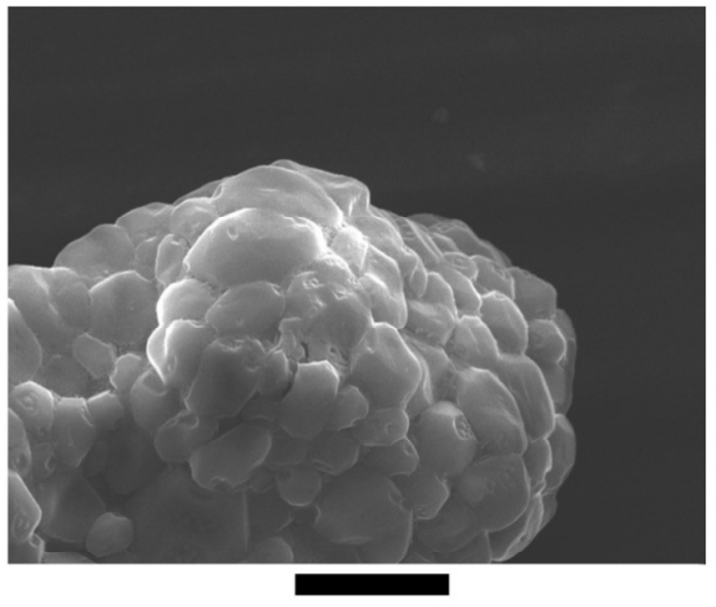

$5.0 \mu \mathrm{m}$ 
Figure S4. XRD patterns of $\mathrm{Ca}_{3} \mathrm{Sc}_{2} \mathrm{Si}_{3} \mathrm{O}_{12}$ calcined at $1100{ }^{\circ} \mathrm{C}-1400{ }^{\circ} \mathrm{C}$.

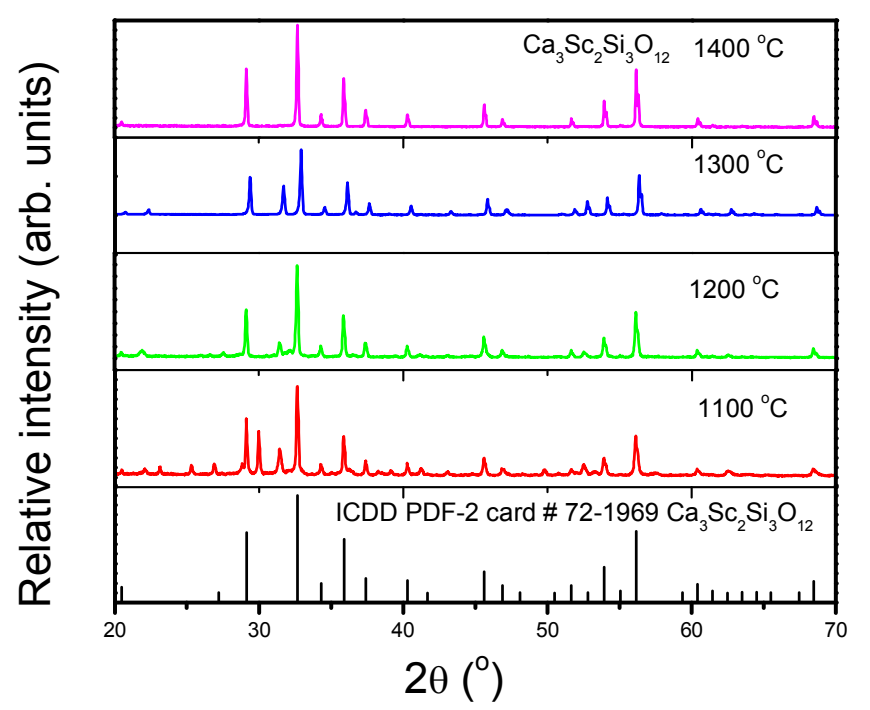

Figure S5. Centroid and crystal field splitting in $\mathrm{Ca}_{3} \mathrm{Sc}_{2} \mathrm{Si}_{3} \mathrm{O}_{12}: \mathrm{Ce}^{3+}, \mathrm{Na}^{+} \mathrm{S} 4$.

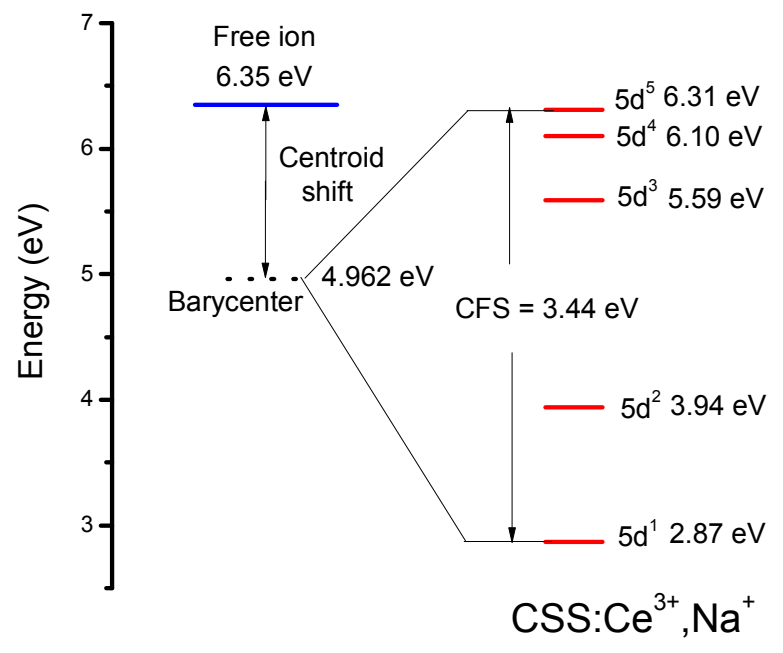


Figure S6. Ce-L3 X-ray absorption near-edge structure in of selected samples.

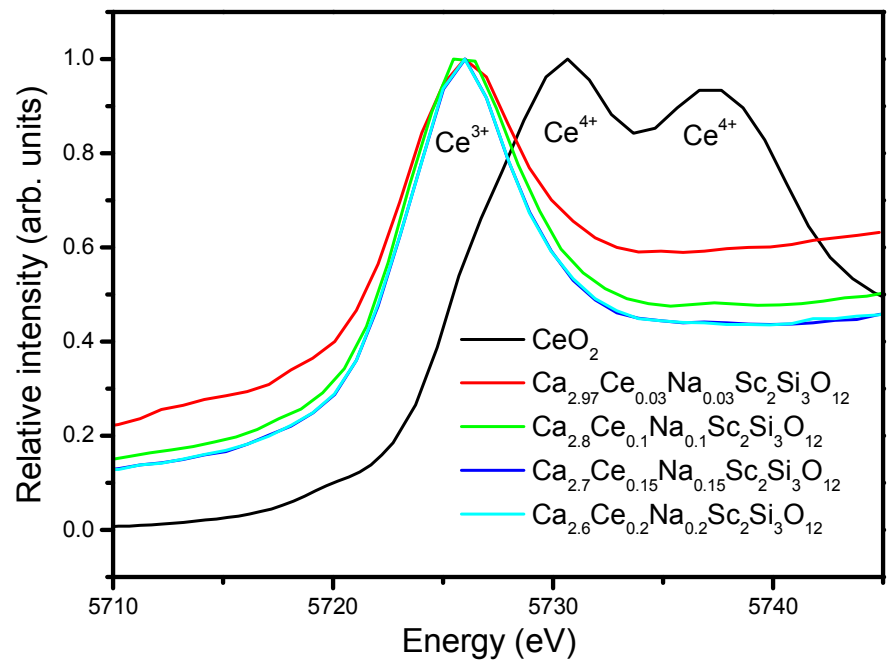

Figure S7. VUV-UV excitation spectra of $\mathrm{Ca}_{2.8} \mathrm{Ce}_{0.1} \mathrm{Na}_{0.1} \mathrm{Sc}_{2} \mathrm{Si}_{3} \mathrm{O}_{12}$ at $15 \mathrm{~K}$.

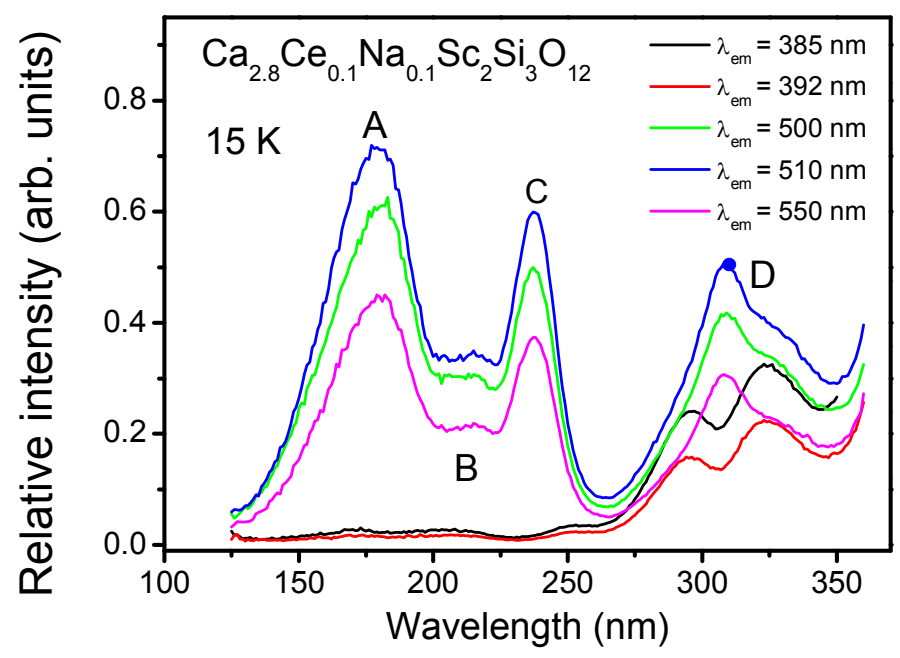


Figure S8. The VUV excitation spectra of $\mathrm{Ca}_{3-2 x} \mathrm{Ce}_{x} \mathrm{Na}_{x} \mathrm{Sc}_{2} \mathrm{Si}_{3} \mathrm{O}_{12}(x=0,0.001,0.1$ and 0.2$)$ at 15 $\mathrm{K}$.

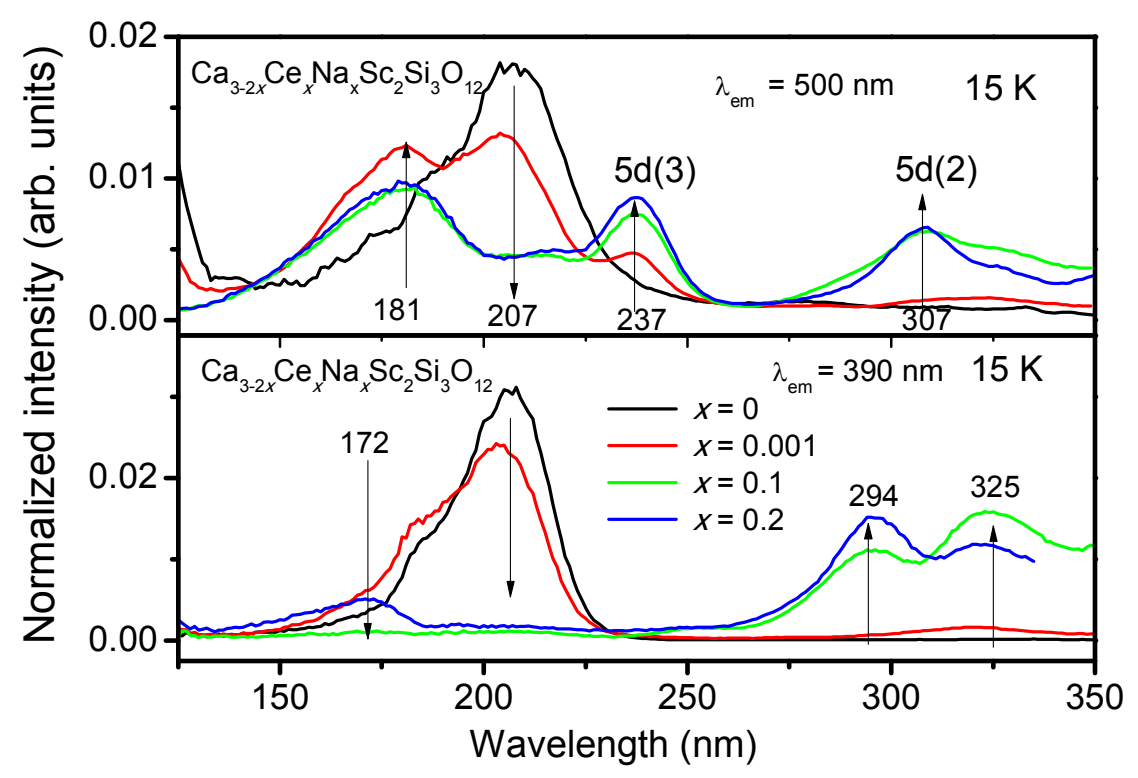

Figure S9. The emission spectra of $\mathrm{Ca}_{2.8} \mathrm{Ce}_{0.1} \mathrm{Na}_{0.1} \mathrm{ScSi}_{3} \mathrm{O}_{12}$ under 330, 360 and $440 \mathrm{~nm}$ excitation wavelengths, respectively at RT.

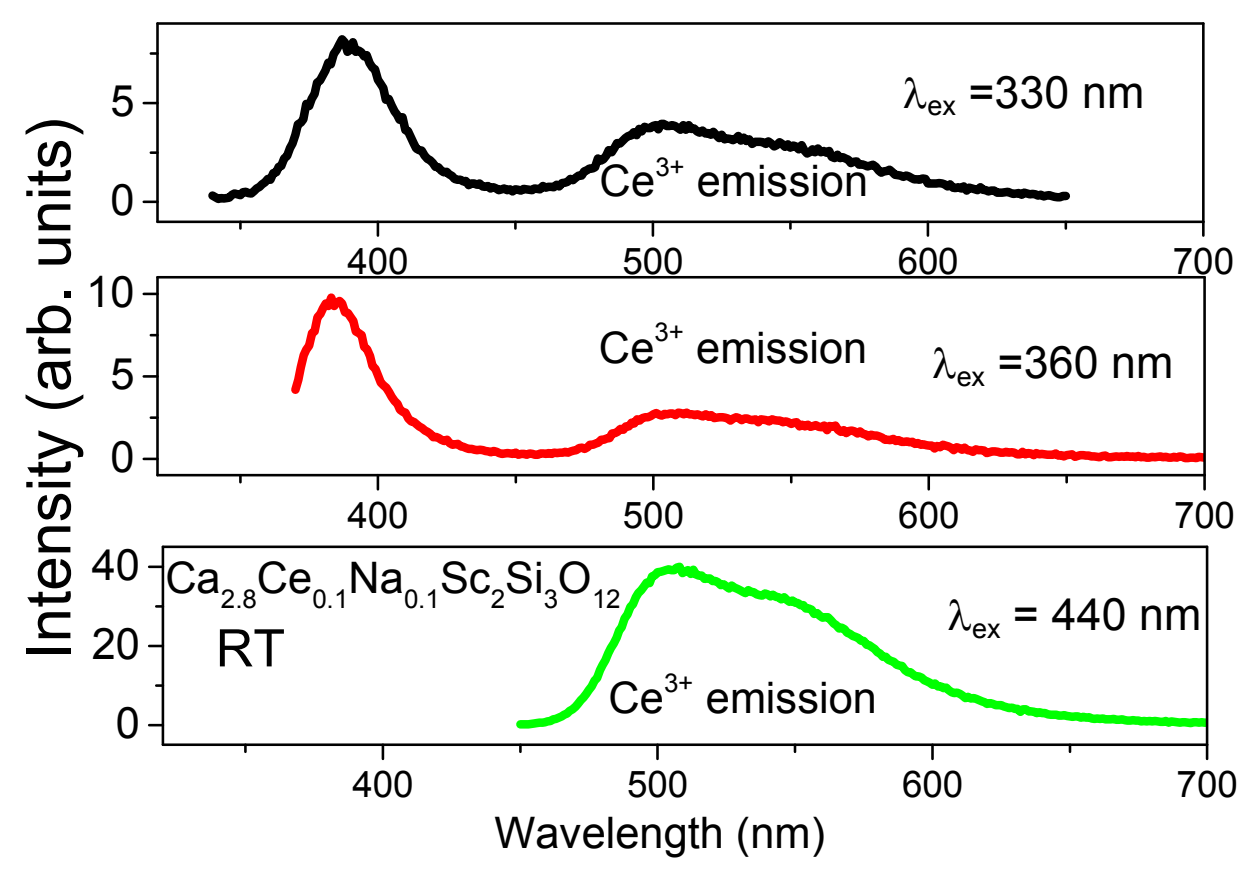


Figure $\mathrm{S} 10$. The emission spectra of $\mathrm{Ca}_{2.8} \mathrm{Ce}_{0.1} \mathrm{Na}_{0.1} \mathrm{ScSi}_{3} \mathrm{O}_{12}$ at $15 \mathrm{~K}$ excited by synchrotron radiation.

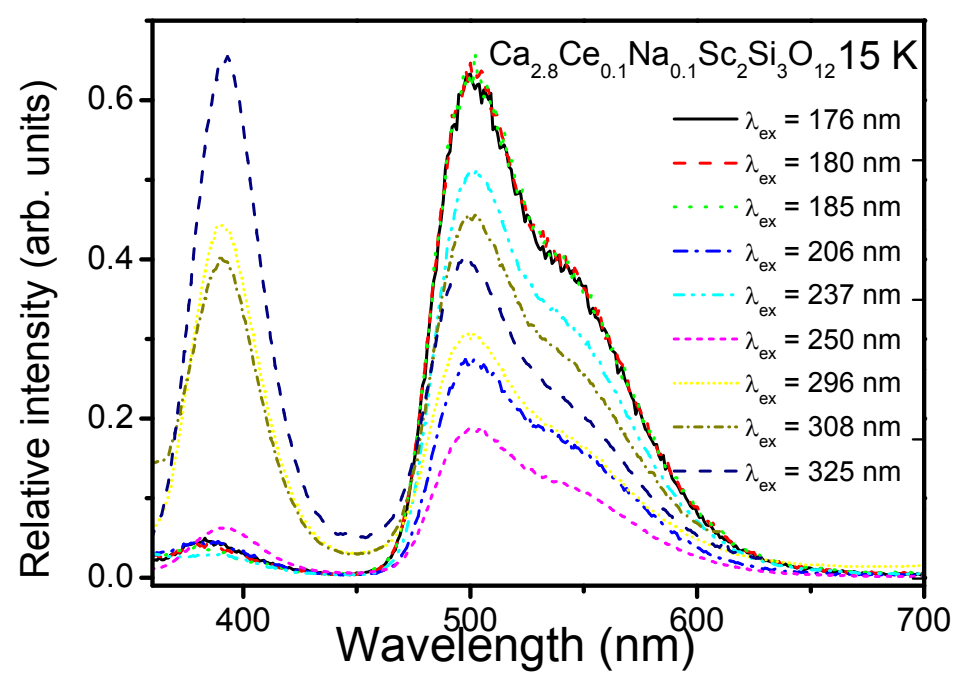

Figure $\mathrm{S} 11$. The emission decay curves of $\mathrm{Ca}_{2.8} \mathrm{Ce}_{0.1} \mathrm{Na}_{0.1} \mathrm{ScSi}_{3} \mathrm{O}_{12}$ at $15 \mathrm{~K}$.

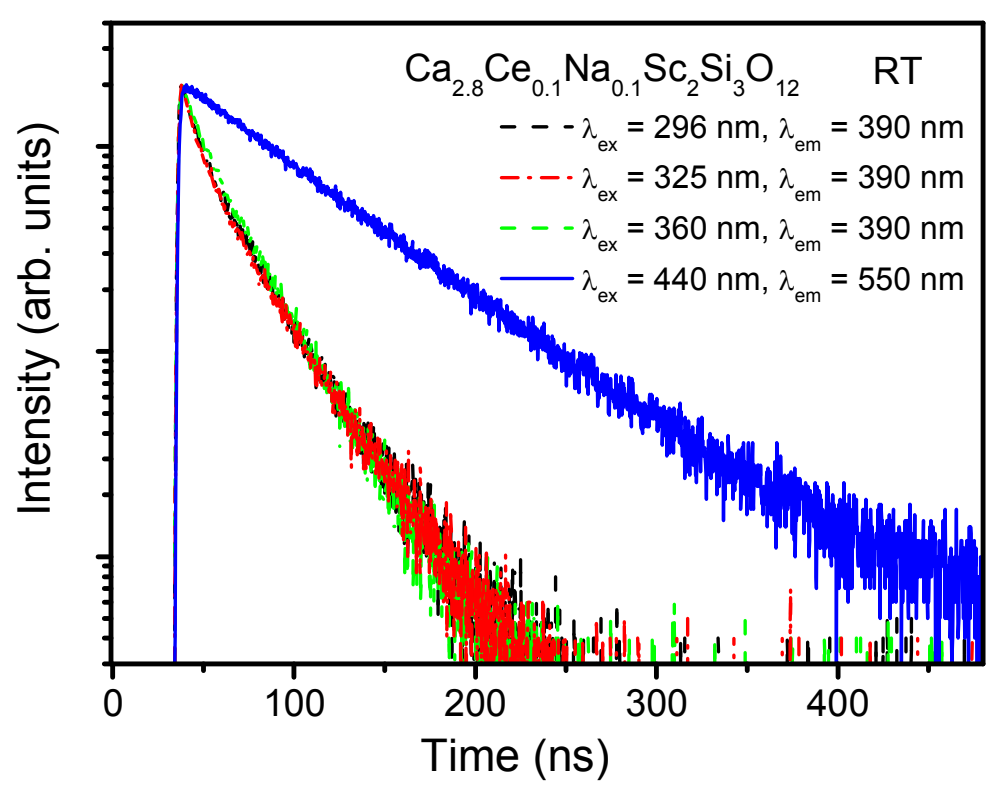


Figure S12.The normalized excitation spectra (according to the highest peak intensity) of $\mathrm{Ca}_{2.8} \mathrm{Ce}_{0.1} \mathrm{Na}_{0.1} \mathrm{Sc}_{2} \mathrm{Si}_{3} \mathrm{O}_{12}$ at various temperatures by monitoring $550 \mathrm{~nm}$ emission.

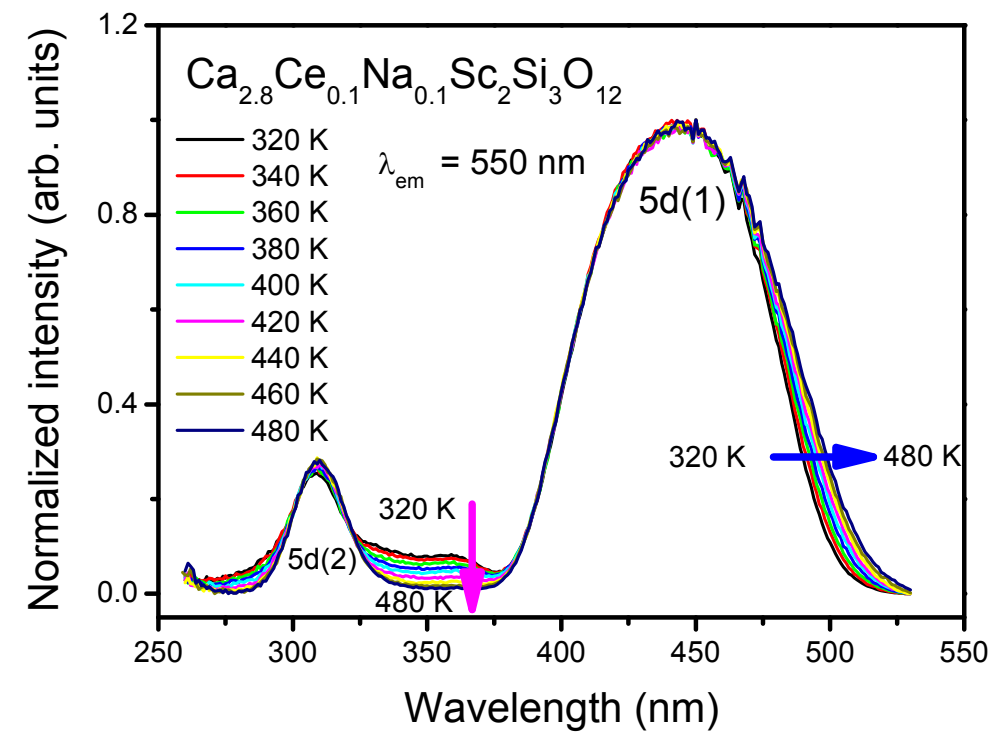

Figure S13. $13 \mathrm{~K}$ emission and excitation spectra of CSS:0.06 Eu.

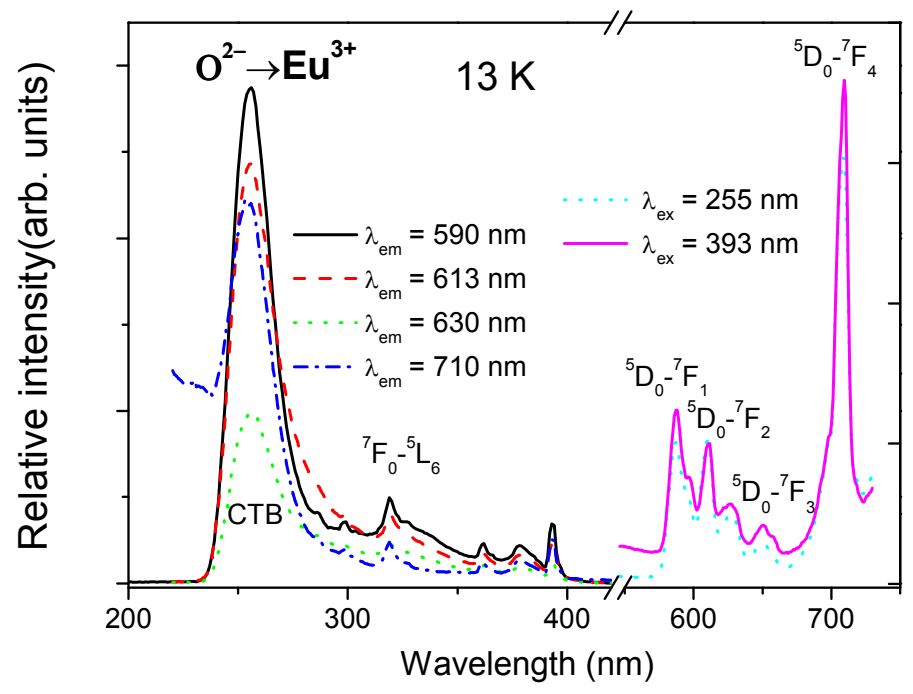


Figure $\mathrm{S} 14$. The excitation and emission spectra of $\mathrm{Ca}_{2.94} \mathrm{Eu}_{0.06} \mathrm{Sc}_{2} \mathrm{Si}_{3} \mathrm{O}_{12}$ at $13 \mathrm{~K}$.

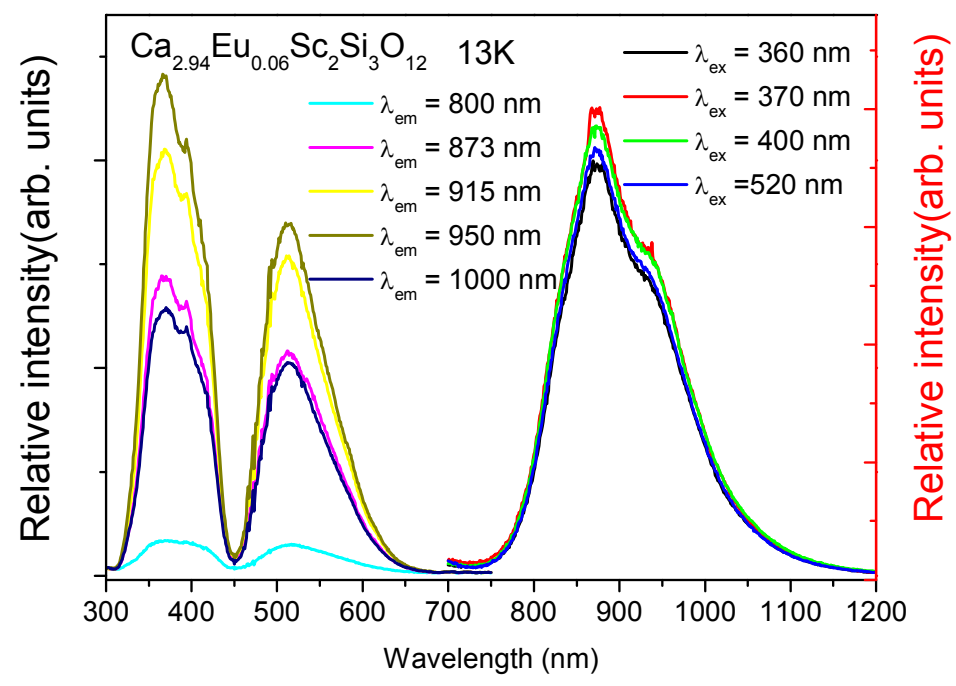

Figure $\mathrm{S} 15$. The excitation spectra of the samples $\mathrm{Ca}_{3-x} \mathrm{Eu}_{x} \mathrm{Sc}_{2} \mathrm{Si}_{3} \mathrm{O}_{12}(x=0-0.09)$ at RT.

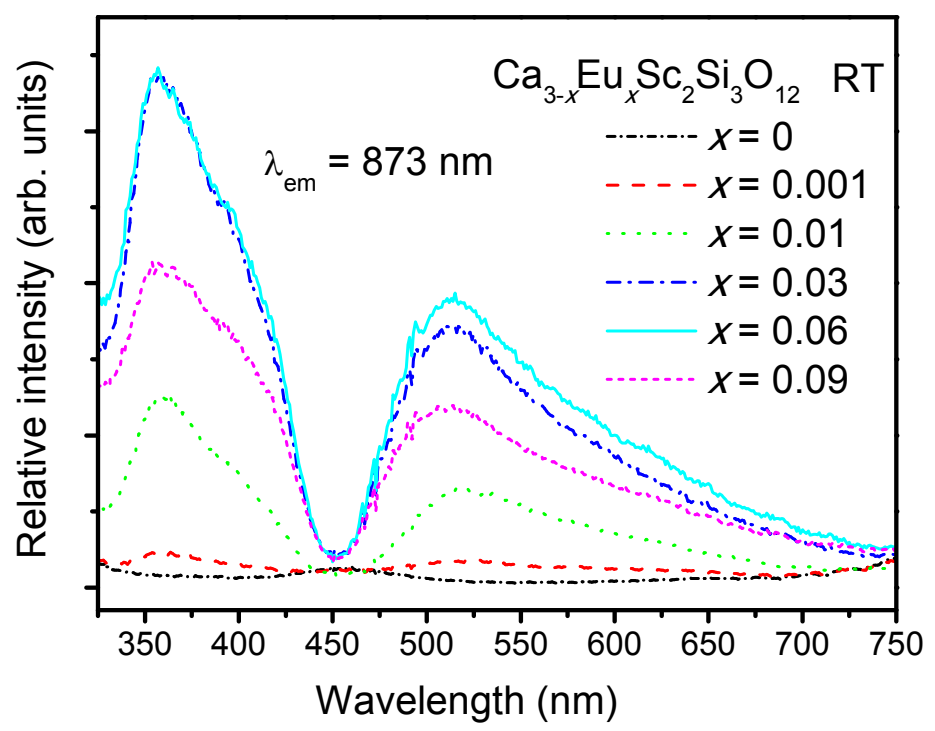


Figure $\mathrm{S} 16$. The decay curves of $\mathrm{Ca}_{3-x} \mathrm{Eu}_{x} \mathrm{Sc}_{2} \mathrm{Si}_{3} \mathrm{O}_{12}$ at $\mathrm{RT}$.

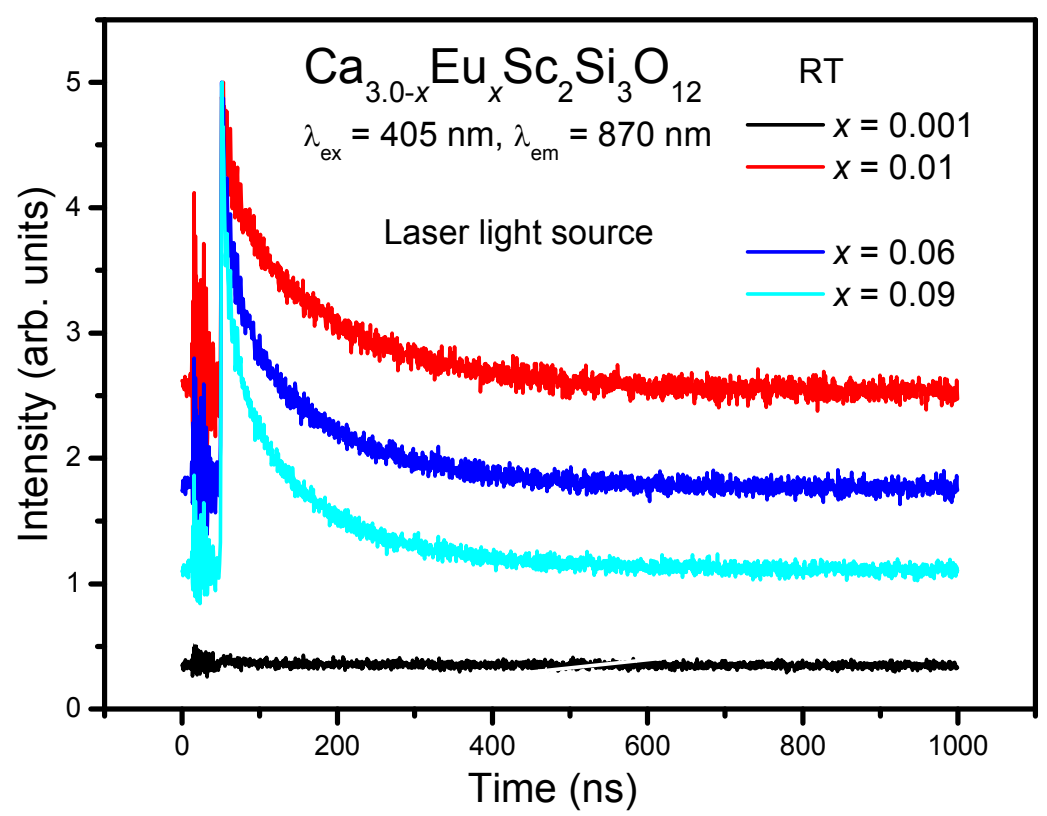

Figure S17. (a) The emission spectra for samples of $\mathrm{Ca}_{2.94} \mathrm{Eu}_{0.06} \mathrm{Sc}_{2} \mathrm{Si}_{3} \mathrm{O}_{12}$ at different temperatures. Repeated experiments (at different resolution). (b) The temperature dependence of emission was fitted according to the equation: $[\mathrm{I}(T) / \mathrm{I}(0)]=1 /[1+\exp (-E / k T)]$, where $\mathrm{I}(T)$ is the integrated emission band area at temperature $T / \mathrm{K}, E$ is an activation energy and $k$ is the Boltzmann constant. $I(0)$ was taken as the value at $25 \mathrm{~K}$. 

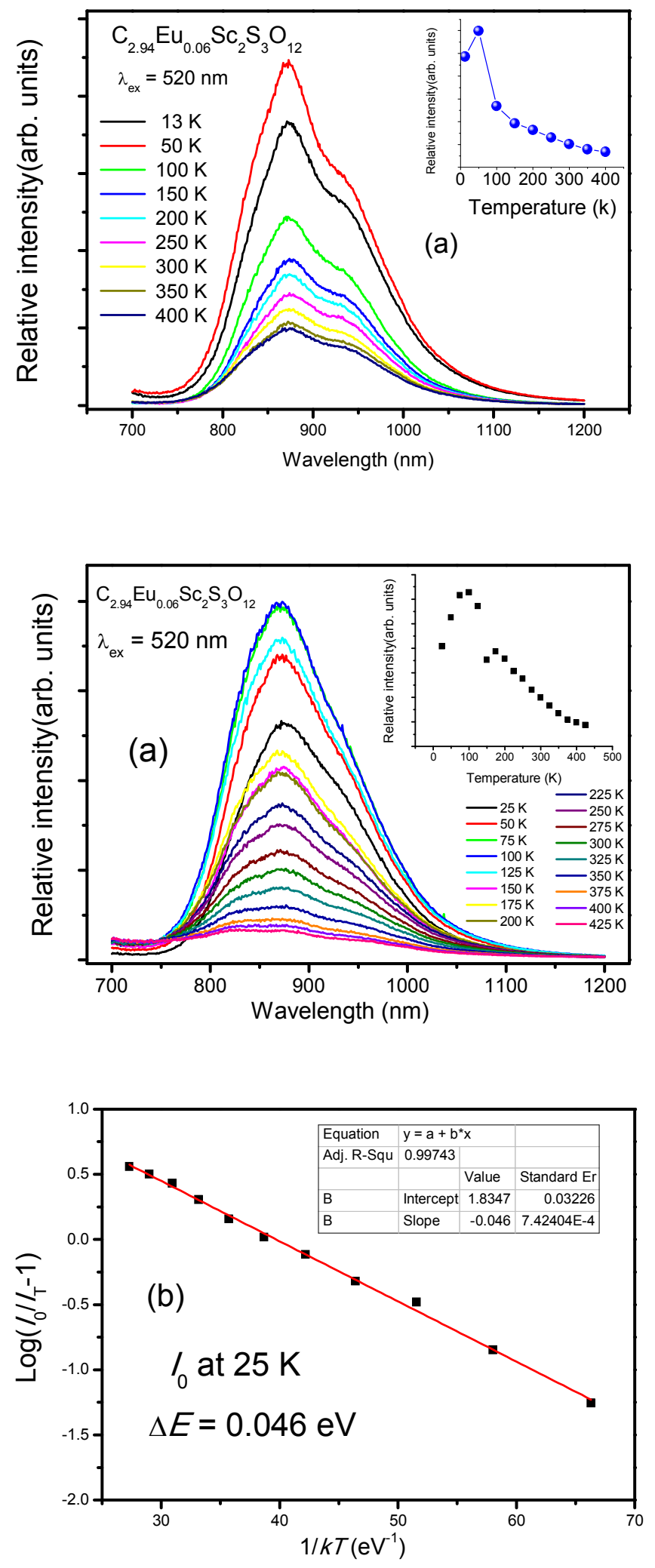
Figure S18. The excitation spectra of co-doped samples $\mathrm{Ca}_{2.8} \mathrm{Ce}_{0.1} \mathrm{Na}_{0.1} \mathrm{Eu}_{x} \mathrm{ScSi}_{3} \mathrm{O}_{12}$ at $\mathrm{RT}\left(\lambda_{\text {em }}=\right.$ $550 \mathrm{~nm})$.

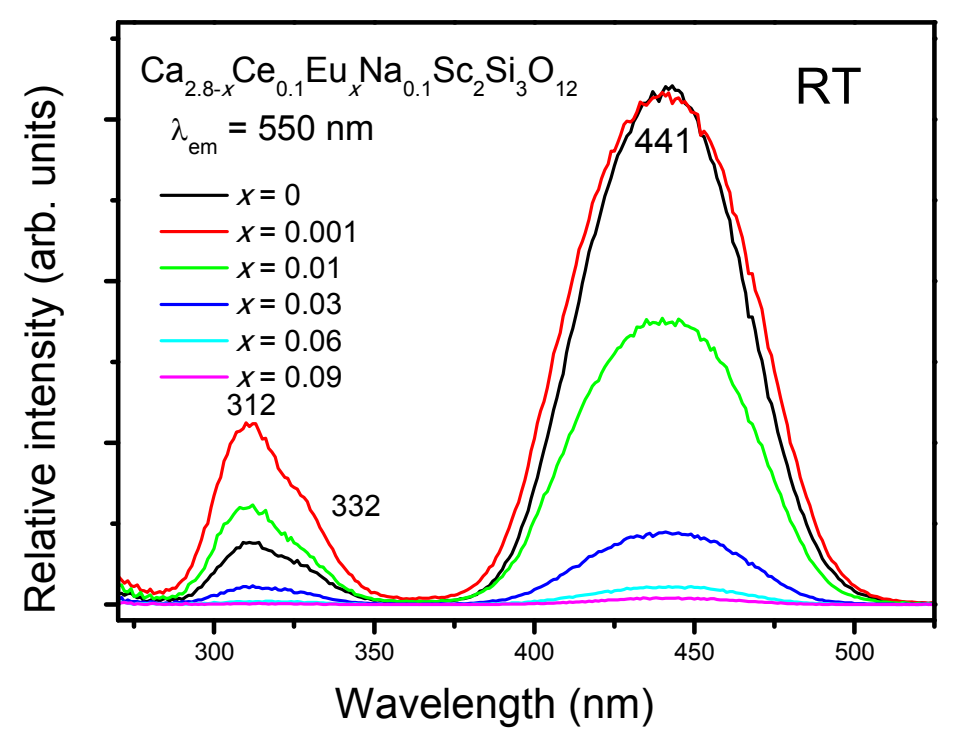

Figure S19. The emission spectra $\left(\lambda_{\text {em }}=440 \mathrm{~nm}\right)$ of $\mathrm{Ca}_{2.8-x} \mathrm{Ce}_{0.1} \mathrm{Eu}_{x} \mathrm{Na}_{0.1} \mathrm{Sc}_{2} \mathrm{Si}_{3} \mathrm{O}_{12}$ at room temperature. 


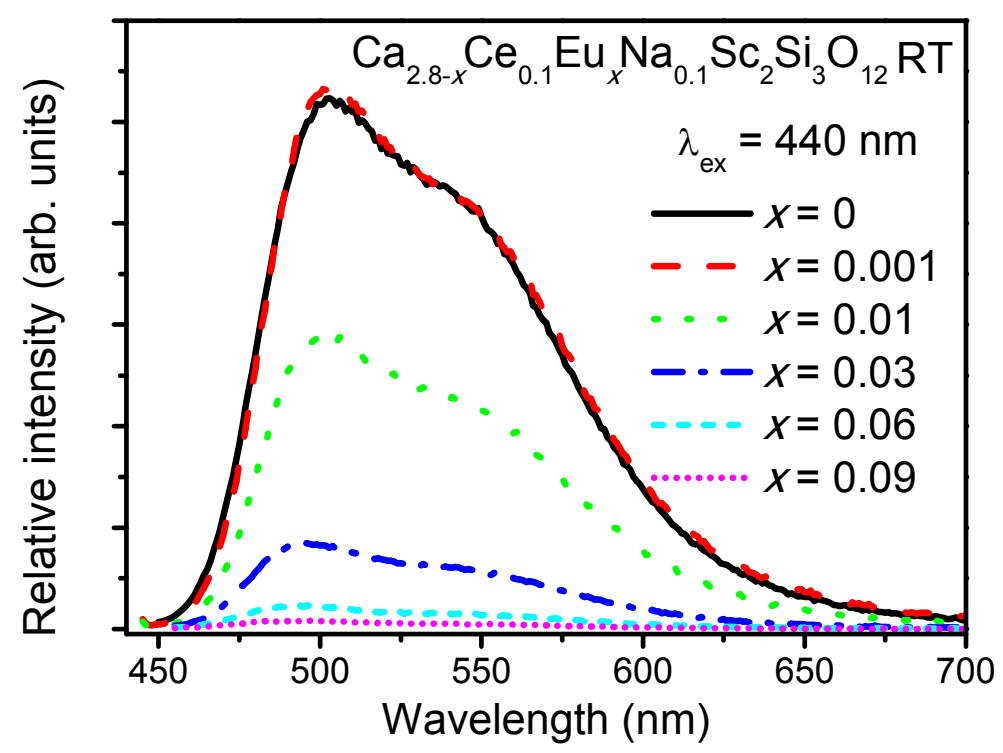

Figure S20. Inokuti-Hirayama fits of $\mathrm{Ca}_{2.8-x} \mathrm{Ce}_{0.1} \mathrm{Eu}_{x} \mathrm{Na}_{0.1} \mathrm{Sc}_{2} \mathrm{Si}_{3} \mathrm{O}_{12}$ for $s=10$.

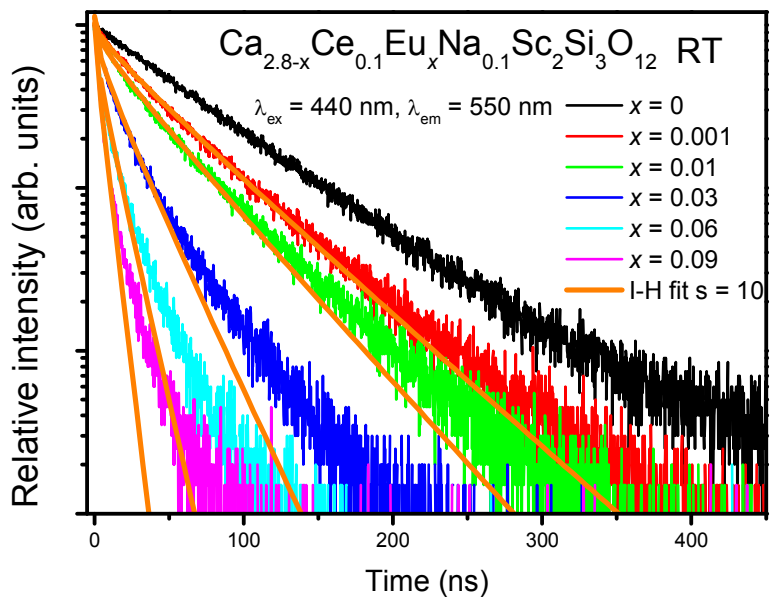


Figure S21. The spectral overlap of the $\mathrm{Ce}^{3+}$ emission spectrum and $\mathrm{Eu}^{2+}$ excitation spectrum.

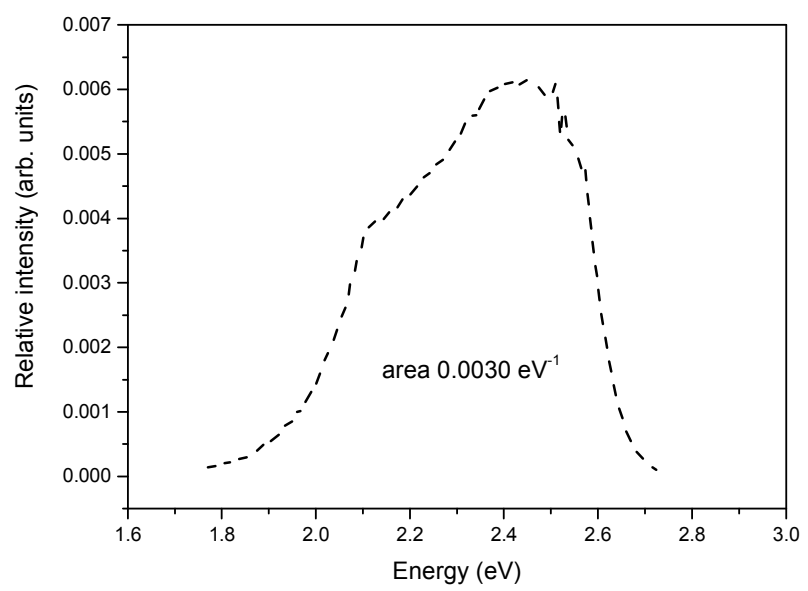

The critical distance of $\mathrm{Ce}^{3+}$ energy transfer, $R_{0}$, can be described by the Dexter formula: ${ }^{\mathrm{S} 5}$

$R_{0}^{6}=3.024 \times 10^{12} \times \frac{f_{O S C}}{E^{4}} \times S O$

Where $f_{\text {osc }}$ is the oscillator strength of the donor optical absorption transition, often estimated as 0.01 for broad f-d transitions; ${ }^{\mathrm{S} 5} \mathrm{E}$ is the energy of maximum overlap and $S O$ is the spectral overlap of the normalized spectral shapes of the $\mathrm{Ce}^{3+} \mathrm{d}-\mathrm{f}$ emission and the $\mathrm{Eu}^{2+} \mathrm{f}-\mathrm{d}$ excitation, with the value of $0.003 \mathrm{eV}^{-1}$ (Figure S21). Therefore, $R_{0}$ is estimated to be $25 \AA$.

\section{References}

S1 Ding, X.; Liang, H.; Hou, D.; Jia, S.; Su, Q.; Sun, S.; Tao, Y. Site occupancy and luminescence of $\mathrm{Ce}^{3+}$ in $\mathrm{NaSr}_{4}\left(\mathrm{BO}_{3}\right)_{3}$. J. Phys. D: Appl. Phys., 2012, 45, 365301(6pp).

S2 Ni, H.; Liang, H.; Xie, M.; Chen, W.; Su, Q.; Tao, Y.; Gao, Z. Temperature Sensitive Luminescence of $\mathrm{Ce}^{3+}$ in Two Different Sites of $\mathrm{Na}_{3} \mathrm{LuSi}_{2} \mathrm{O}_{7}$. J. Electrochem. Soc., 2012 159(3): J43-J47.

S3 Ding, W.; Wen, J.; Cheng, J.; Ning, L. X.; Huang, Y. C.; Duan, C. K.; Yin, M. Chin. FirstPrinciples Study of $\mathrm{Ca}_{3} \mathrm{Sc}_{2} \mathrm{Si}_{3} \mathrm{O}_{12}$ : $\mathrm{Ce}^{3+}$ Phosphors. Chin. J. Chem. Phys., 2015, 28, 150-154.

S4 Henderson, B.; Imbusch, G. F. Optical Spectroscopy of Inorganic Solids, Clarendon Press, Oxford. 1989. p. 448, Eqs. 10.9-10.12 and Figure 10.5, p. 458. 
S5 Dexter, D. L. J. Chem. Phys., 1953, 21, 836-850. 